\title{
Synchrony and desynchrony in circadian clocks: impacts on learning and memory
}

\author{
Harini C. Krishnan and Lisa C. Lyons \\ Department of Biological Science, Program in Neuroscience, Florida State University, Tallahassee, Florida 32306, USA
}

\begin{abstract}
Circadian clocks evolved under conditions of environmental variation, primarily alternating light dark cycles, to enable organisms to anticipate daily environmental events and coordinate metabolic, physiological, and behavioral activities. However, modern lifestyle and advances in technology have increased the percentage of individuals working in phases misaligned with natural circadian activity rhythms. Endogenous circadian oscillators modulate alertness, the acquisition of learning, memory formation, and the recall of memory with examples of circadian modulation of memory observed across phyla from invertebrates to humans. Cognitive performance and memory are significantly diminished when occurring out of phase with natural circadian rhythms. Disruptions in circadian regulation can lead to impairment in the formation of memories and manifestation of other cognitive deficits. This review explores the types of interactions through which the circadian clock modulates cognition, highlights recent progress in identifying mechanistic interactions between the circadian system and the processes involved in memory formation, and outlines methods used to remediate circadian perturbations and reinforce circadian adaptation.
\end{abstract}

Circadian clocks permit organisms to anticipate recurring daily environmental events through the coordination of metabolic, physiological, and behavioral rhythms. Conservation of the core principles through which circadian oscillators are organized across eukaryotic phyla suggests strong selective pressures for both circadian clocks and the mechanisms through which circadian oscillators operate. Intracellularly, transcription/translation feedback loops involving core circadian components set the stage for transcriptional regulation of thousands of genes in individual cells and tissues (Balsalobre et al. 2000b; McDonald and Rosbash 2001; Panda et al. 2002; Yoo et al. 2004; Doherty and Kay 2010; for recent review of mammalian circadian oscillators, see Buhr and Takahashi 2013). Circadian oscillators operate within single cells using neuropeptide communication to promote synchronization and coordination of output regulation, primarily vasoactive intestinal peptide (VIP) for coordination of circadian pacemaker neurons within the suprachiasmatic nucleus (SCN) in mammals with other contributing neurotransmitters (Aton et al. 2005; Maywood et al. 2006, 2011; Evans et al. 2013) and pigment-dispersing factor (PDF) in fruit flies (Renn et al. 1999; Duvall and Taghert 2012). At a systems level, the SCN within the hypothalamus broadly acts as the master circadian clock in mammals synchronizing circadian oscillators in multiple tissues such as pancreas, adipose tissue, lungs, skeletal muscles, adrenal glands, ovaries, and cell types including neurons, fibroblasts, and islet cells (Honma et al. 2012; Mohawk et al. 2012; Pulimeno et al. 2013; Sellix 2015). This hierarchy stands in contrast to the circadian system in lower vertebrates such as fish or invertebrates, e.g., Drosophila melanogaster, in which independently entrainable oscillators may be found throughout the organism (Plautz et al. 1997; Whitmore et al. 2000). Nonetheless, even in mammals independent peripheral oscillators exist including the food-entrainable oscillator in the liver (Stephan 2002; Saper and Fuller 2007; Mistlberger 2011) and oscillators in the olfactory bulb (Granados-Fuentes et al. 2004; Abraham et al. 2005; Miller et al. 2014).

Corresponding author: lyons@bio.fsu.edu Article is online at http://www.learnmem.org/cgi/doi/10.1101/Im.038877.115.
Circadian rhythms have been observed for centuries in plants (McClung 2006) and animals (for review, see Moore-Ede et al. 1982); however, our understanding of the impact of the circadian clock on disease remained limited for much of the last century despite rapid progress identifying the molecular mechanisms underlying the circadian oscillator. In Drosophila, circadian mutants exhibited few negative consequences altering health, fecundity, or longevity, although more recently reductions in lifespan have been observed for circadian mutants in a sex-specific manner or under stressful conditions (Shaw et al. 2002; Hendricks et al. 2003). Similarly, no adverse health impacts initially were observed in tau, the first identified short period mutant in mammals (Ralph and Menaker 1988), although later studies identified longevity impacts (Hurd and Ralph 1998), significant cardiovascular disease issues (Martino et al. 2007), and a correlation between shorter period length and smaller body size (Refinetti 2014).

\section{Desynchronization of the circadian clock}

Under conditions of circadian perturbation in which environmental conditions abruptly change, e.g., flying across multiple time zones, the temporal synchronization of circadian oscillators with the environment is suspended. Within the SCN, circadian neurons become desynchronized from each other with resynchronization taking 5-7 d after long-phase delays and 9-13 d after long-phase advances (Nagano et al. 2003). Similarly, peripheral oscillators across tissues and organs also need to resynchronize with each other and the SCN, and generally take longer to resynchronize than the SCN (Yamazaki et al. 2000). However, the length of time necessary to achieve stable phases attuned to the new photoperiod varies between tissues and organs (for review, see Harrington 2010), with $\sim 8$ d necessary for full

(C) 2015 Krishnan and Lyons This article is distributed exclusively by Cold Spring Harbor Laboratory Press for the first 12 months after the full-issue publication date (see http://learnmem.cshlp.org/site/misc/terms.xhtml). After 12 months, it is available under a Creative Commons License (AttributionNonCommercial 4.0 International), as described at http://creativecommons. org/licenses/by-nc/4.0/. 
peripheral resynchronization following a $6 \mathrm{~h}$ phase advance (Davidson et al. 2009; Kiessling et al. 2010).

Throughout the last two centuries, technological advances have dramatically changed individual work and rest patterns. (Luckhaupt 2012; Alterman et al. 2013) Individuals increasingly work longer hours with progressively more individuals working nontraditional schedules. In $2004,17.7 \%$ of US workers ( $\sim 15$ million full-time employees) worked hours outside of a traditional day shift (U.S. Bureau of Labor Statistics 2005; McMenamin 2007; Alterman et al. 2013) with that number increasing to $28.7 \%$ by 2010 demonstrating a rapid increase in the scope of nontraditional shift work (Alterman et al. 2013). On a global level, individuals performing shift-work comprise $>15 \%$ of the workforce in many developed countries (for review, see Wright et al. 2013). Across professions and industries, career and economic pressures often extend an individual's working hours with $18.7 \%$ of Americans working $>48 \mathrm{~h}$ per week and $7.2 \%$ working $60 \mathrm{~h}$ or greater (Alterman et al. 2013). However, this number probably underestimates the number of individuals with shift work or extended work-weeks (Grosch et al. 2006; Alterman et al. 2013).

Individuals working traditional schedules also suffer from circadian desynchronization through social jet lag, a phenomenon in which individuals shift their activity and sleep patterns between the work week and the weekend with most individuals sleeping considerably later on weekends (Wittmann et al. 2006; Roenneberg 2013). Social jet-lag results in a bi-weekly phase shifting of the circadian clock similar to individuals with shift-work schedules rotating between day and afternoon-evening shifts. Shift-work and social jet-lag affect individual health, and increase safety risks and economic costs to businesses and society. Misalignment of the circadian system with scheduled work results in increased industrial and occupational accident rates, decreased work productivity, increased traffic accidents, and increases the risk for performance errors with adverse impacts for individuals in healthcare, transportation and public safety professions (Lockley et al. 2007; Keller 2009; Wright et al. 2013).

In the past decade, the adverse impacts of circadian dysfunction on human health have become clear. Desynchronization or aberrant functioning of circadian oscillators result in significant health consequences with increased risk and incidence of obesity, diabetes, cancer, and heart disease as well as other diseases (Barnard and Nolan 2008; Preuss et al. 2008; Arble et al. 2010; Bass and Takahashi 2010; Karatsoreos et al. 2011; Evans and Davidson 2013; Orozco-Solis and Sassone-Corsi 2014; Pluquet et al. 2014). Furthermore, circadian dysfunction may increase susceptibility to mood disorders or the incidence of drug abuse (Logan et al. 2014; Zelinski et al. 2014).

\section{Types of circadian interactions with learning and memory}

The circadian clock broadly affects metabolic and physiological processes with adverse consequences to the individual when circadian oscillators are desynchronized, so it is not surprising that memory and cognitive performance also are under circadian control. There is a critical need for identifying and understanding the mechanisms through which the circadian clock affects memory and cognitive performance. Four major interactions of the circadian clock with the processes of learning and memory will be reviewed (Fig. 1): (1) the impact of circadian dysfunction on memory, (2) circadian modulation of memory formation or recall, (3) daily time place learning, a temporal-spatial form of learning that incorporates time-stamping, and (4) interactions between the circadian clock, aging, and neurodegenerative diseases.

\section{Circadian dysfunction and memory}

Desynchronization or misalignment of circadian oscillators causes decrements in cognitive function as observed in animal models and humans. Chronic jet lag lasting several years decreases cognitive performance in flight crews compared with flight crews routinely crossing less than three time zones (Cho et al. 2000). Moreover, these cognitive decrements were accompanied by higher cortisol levels and temporal lobe atrophy (Cho 2001). Experimental jet-lag conditions in hamsters also resulted in persistent long-term cognitive deficits in spatial memory accompanied by significant decreases in cell proliferation and hippocampal neurogenesis (Gibson et al. 2010). The severity of neurogenesis deficits are direction dependent with phase advances resulting in greater suppression of hippocampal neurogenesis (Kott et al. 2012). Circadian disruption through constant light conditions (Daan and Pittendrigh 1976) decreases performance in the Morris water maze along with hippocampal neurogenesis (Fujioka et al. 2011). In wild-type hamsters with the SCN intact, induction of circadian dysrhythmia impairs spatial and recognition memory (Fernandez et al. 2014). Acute experimental jet lag also disrupts recall of longterm contextual fear conditioning in mice (Loh et al. 2010). As seen with many learning paradigms, acute circadian phase shifts
A
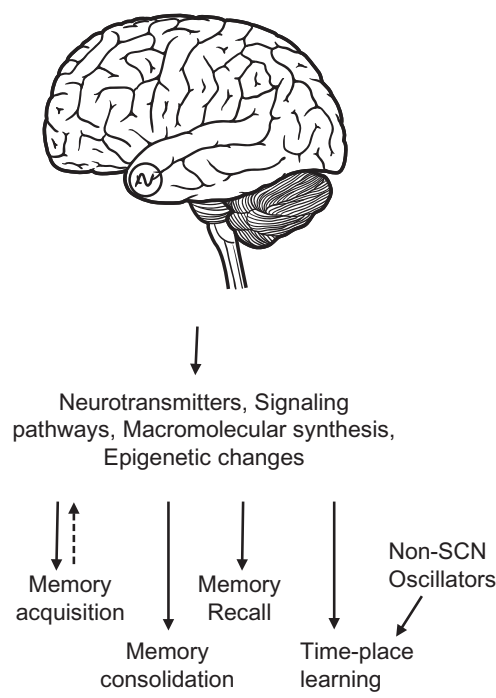

Figure 1. Interactions between the circadian oscillator and memory. ( $A$ ) The circadian clock modulates learning and memory by interacting with underlying molecular mechanisms. (B) Desynchronization of the circadian clock by environmental and behavioral factors leads to cognitive impairments. 
following training produce deficits in memory recall and retrograde amnesia (Tapp and Holloway 1981; Fekete et al. 1985; Devan et al. 2001; see Smarr et al. 2014 for additional examples and discussion of rodent models).

Recent occupational studies found significant cognitive impairments in long-time shift workers (Rouch et al. 2005; Marquié et al. 2015), with a cognitive loss equivalent of $6.5 \mathrm{yr}$ compared with age-related decline cohorts (Marquié et al. 2015). While these deficits are, at least, partially reversible (Rouch et al. 2005), the cognitive decrements in long-time shift workers ( $>10 \mathrm{yr}$ ) persist for $5 \mathrm{yr}$ after the conclusion of shift work (Marquié et al. 2015). Even for experienced shift workers, short-term memory (STM) is compromised after night work (Meijman et al. 1993). Thus, the desynchronization and misalignment of the circadian system caused by shift work or jet lag significantly decreases memory and performance in addition to increasing the incidence and risk of many diseases.

\section{Circadian rhythms in memory acquisition, recall, and extinction}

Under normal conditions, daily modulation of learning and memory is observed across species ranging from invertebrates to humans. The scope and complexity of circadian modulation can be illustrated using invertebrate models of learning. In the diurnal Aplysia californica, peak intermediate (ITM) and long-term memory (LTM) formation for nonassociative and associative learning paradigms occur during the day in coordination with the animal's activity period (Fernandez et al. 2003; Lyons et al. 2005, 2008) while LTM in nocturnal Aplysia fasciata peaks during the night (Lyons et al. 2005). However, circadian modulation of memory may occur independently of circadian regulation of rest/activity cycles. Despite the difference in activity between crepuscular Drosophila and nocturnal cockroaches, short and long-term olfactory memory arising from classical conditioning in both models is modulated by the circadian clock with peak performance during the early (subjective) night (Decker et al. 2007; Lyons and Roman 2009; Fropf et al. 2014). Bees demonstrate more robust learning when trained and tested early in the day relative to other time points and independent of the feeding schedule (Lehmann et al. 2011). Thus, the phase of circadian peaks and troughs in memory varies between learning paradigms and species, potentially entwined with coordination of related behaviors and processes.

In rodents, acquisition of hippocampal-dependent learning paradigms such as Morris water maze, contextual fear conditioning, and the radial arm maze, is higher during the night (Hauber and Bareiss 2001; Valentinuzzi et al. 2001, 2004). Similarly in hippocampal long-term potentiation, the amplitude of population spikes is significantly greater during the night (Chaudhury et al. 2005). Furthermore, memory persistence is dependent upon time of training with increased retention observed when nocturnal rodents were trained during the night for spatial learning or an operant sustained attention task (Gritton et al. 2012). In all of these studies, time of training appears to be the critical factor in predicting memory strength suggesting that circadian clock regulates training-induced processes in memory formation. However, the circadian clock may independently modulate the recall of memory. Recall of cued fear conditioning in mice peaks in the early day irrespective of the time of training (Chaudhury and Colwell 2002). Likewise in cockroaches, the recall of operant olfactory conditioning rather than memory formation is regulated by the circadian clock (Garren et al. 2013).

Multiple factors, including homeostatic sleep pressure, sleep inertia, and circadian modulation, interact to affect memory and cognitive performance and discriminating between these elements can be difficult in humans. However, forced desynchrony models in which circadian rhythms are disconnected from rest periods have allowed researchers to separately analyze contributions of homeostatic sleep pressures, sleep inertia, and circadian processes on cognitive performance (Czeisler et al. 1994; Lee et al. 2009; Cohen et al. 2010; Grady et al. 2010; Silva et al. 2010). Upon awakening and early in the day, cognitive performance is lower due to sleep inertia and low circadian stimulation of brain arousal (for review, see Wright et al. 2012). Throughout the day alertness and performance decrease in response to extended time awake indicative of homeostatic regulation and fatigue. Persisting circadian up-regulation of arousal, alertness, and cognitive performance counteracts the homeostatic drive, particularly during the late afternoon and evening (Wright et al. 2002, 2012; Reid et al. 2011). In humans, the circadian clock regulates cognitive performance such that learning and performance are lower during the night (Wright et al. 2006; Gerstner et al. 2009).

In addition to memory acquisition and recall, the extinction of memory and even memory forgetting are active regulated processes (Hardt et al. 2013; Berry and Davis 2014). In rodent models, extinction of conditioned fear peaks in the early night similar to the rhythm observed for the initial contextual conditioned fear memory (Valentinuzzi et al. 2001; Woodruff et al. 2015). In studies of healthy men, extinction learning was faster with more robust memory apparent when learning trials occurred in the early morning compared with the late evening (Pace-Schott et al. 2013). Furthering our understanding of the circadian modulation of memory processes and extinction learning could facilitate improved treatments of post-traumatic stress disorder and other mood disorders.

Bidirectional interactions occur between the circadian system and memory processes with more complex learning paradigms affecting circadian entrainment. For a sustained attention task, repeated training out of phase with the animals' activity pattern in rats shifted and entrained circadian locomotor activity rhythms (Gritton et al. 2009, 2012, 2013). Entrainment through this non-photic signal relied primarily upon basal forebrain cholinergic projections to the SCN (Gritton et al. 2013). Interestingly, cognitive entrainment of locomotor activity rhythms also occurred in SCN-lesioned arrhythmic animals demonstrating the potential for entrainment through extraSCN oscillators (Gritton et al. 2013). Thus, the circadian clock modulates the acquisition and formation of memory, but the performance of complex learning tasks out of phase with an animal's activity patterns may also reset circadian activity patterns. Potentially, for long-term shift workers increasing cognitive demand and sustained attention tasks during work could facilitate and maintain circadian alignment with the scheduled work shift.

\section{Time-stamping and circadian time place learning}

The time of day a learning event occurs also can become part of the memory framework. In time-stamping and circadian time place learning, the time of day becomes incorporated into the context during memory formation such that animals demonstrate significantly greater memory at the same circadian time that training occurred (i.e., at 24-h intervals), presumably when the memory would be ethologically relevant (Cain et al. 2004, 2008; Valentinuzzi et al. 2008). Time-stamping effects have been broadly observed for active and passive avoidance learning (Holloway and Wansley 1973), conditioned place preference (Ralph et al. 2002; Valentinuzzi et al. 2008; Monclaro et al. 2014), and 
conditioned place avoidance (Cain et al. 2004, 2008). In the golden hamster, temporal encoding of information as a contextual component of memory can be independent of the SCN as animals with lesioned SCNs demonstrate time of day memory similar to wild-type animals (Ko et al. 2003; Cain and Ralph 2009). Both the canonical SCN oscillator and nontraditional oscillators may encode temporal information for time-stamped memories as taumutant animals with a behaviorally short period of $20 \mathrm{~h}$ demonstrate peak recall of conditioned place avoidance at both 20 and 24 $\mathrm{h}$ after training, with the 20-h rhythm eliminated in SCN-lesioned animals (Cain et al. 2014).

In more complex learning situations in which the animal chooses between multiple spatial locations at different times of day, circadian or daily time place learning provides the animal with the ability to link events (rewarding or aversive) in a spatiotemporal manner (Biebach et al. 1991; Mistlberger et al. 1996; Van der Zee et al. 2008). In the 1920s, Beling's detailed observations of bees demonstrated that honeybees returned to specific locations at times associated with food reward (Moore-Ede et al. 1982). Mice use circadian time place learning in risk assessment paradigms in which the animal associates the spatial location (maze arm) and time of day with a negative cue (footshock) (Van der Zee et al. 2008). Circadian time place learning permits optimization of resource localization with risk assessment such as predator avoidance. In time place learning, the incorporation of temporal information may also occur through extra-SCN or noncanonical oscillatory mechanisms as rats with lesioned SCNs continue to show time-of-day discrimination in a two-lever T-maze test (Mistlberger et al. 1996). When food comprises the reward component in time place learning, the food-entrainable oscillator may be responsible for conveyance of temporal information (Aragona et al. 2002; Mulder et al. 2013). However, the mechanism through which temporal information in time place learning remains unknown as animals with mutations in two of the circadian period genes (Per1-/-;Per $2-/-$ ) show no difference in time place learning when compared with wild-type mice (Mulder et al. 2013). Reception and transmission of temporal information to the unknown oscillator still appears to require Cryptochrome (CRY), a light sensitive clock molecule and core component of the mammalian circadian clock, as CRY double knockout mice $\left(\mathrm{Cry}^{-/-} ; \mathrm{Cry}^{-/-}\right)$are unable to acquire time place learning (Van der Zee et al. 2008).

\section{The circadian clock, aging, and neurodegenerative diseases}

Dampening of circadian rhythms, phase alterations, and circadian desynchrony occur with aging across species ranging from invertebrates to humans (Sloan et al. 1999; Yamazaki et al. 2002; Cajochen et al. 2006; Nakamura et al. 2011; Zhdanova et al. 2011; Farajnia et al. 2012). Furthermore, aging decreases the ability of circadian pacemaker neurons within the SCN to resynchronize following circadian perturbation and increases the time necessary for resynchronization of central and peripheral oscillators (Davidson et al. 2008; Sellix et al. 2012). Prolonged circadian desynchronization can lead to increased mortality in aged animals (Davidson et al. 2006). Age-associated alterations in circadian rhythms also impact memory and performance in animal models (Haley et al. 2009; Kondratova et al. 2010; Nakamura et al. 2011), while in older individuals, fragmentation of rest-activity cycles is correlated with cognitive decline in mental speed, memory, and executive function (Oosterman et al. 2009). The interaction between circadian rhythms and cognitive function in aged individuals represents an area of escalating concern given the rising age of modern societies.
In addition to circadian alterations occurring with normal aging, neurodegenerative disorders associated with aging, including Alzheimer's, Parkinson's, and Huntington's diseases, are correlated with disordered circadian rhythms and disrupted sleep patterns (Hatfield et al. 2004; Nieoullon et al. 2008; Wulff et al. 2010; Cermakian et al. 2011; Videnovic et al. 2014; Musiek 2015). Traditionally, circadian and sleep disorders associated with neurodegenerative diseases have been viewed as symptomatic of these diseases as circadian disorders often correlate with disease severity and rhythms deteriorate with disease progression. However, recent research suggests circadian dysfunction contributes to and escalates neurodegenerative pathologies (Musiek 2015). In clinical studies, dampened or shifted circadian rhythms in aging individuals were predictive of increased risk of mild cognitive impairments and dementia (Tranah et al. 2011; Schlosser Covell et al. 2012). Similarly, weaker circadian rhythms were also predictive of future cognitive impairments in older individuals without dementia (Walsh et al. 2014). The predictive value of dampened circadian rhythms for future impairments suggests that age-associated circadian dysfunction aggravates cognitive decline introducing the possibility of circadian rhythm reinforcement as a therapeutic component during treatment of age-related memory impairments. In a mouse model of Huntington's disease, pharmacological manipulation of rest/activity cycles or scheduled feeding as reinforcement of circadian rhythms mitigated metabolic, circadian, and cognitive impairments (Pallier et al. 2007; Oosterman et al. 2009; Pallier and Morton 2009; Maywood et al. 2010). Reinforcing or strengthening circadian rhythms may represent potential treatment options to slow progression of neurodegenerative diseases and the accompanying cognitive declines.

\section{Function of circadian interactions with memory}

The numerous interactions between the circadian system and memory make discernment of the function(s) of circadian modulation challenging. Circadian regulation of memory presumably arose and was maintained through natural selection. In molluscan models, peak memory formation for intermediate and longterm memory occurs in phase with the animal's activity period (Fernandez et al. 2003; Wagatsuma et al. 2004; Lyons et al. 2005, 2008; Michel et al. 2013). Similarly in rodents, peak performance in the Morris water maze for the diurnal grass rat occurs during the day, while peak performance at night is observed for nocturnal animals (Valentinuzzi et al. 2004; Martin-Fairey and Nunez 2014). However, core circadian gene expression in the SCN appears similarly phased in nocturnal and diurnal rodent species, suggesting that the contrasting phases of memory formation are regulated downstream from the master circadian clock. Neurons of the hippocampus and the amygdala exhibit rhythms in core circadian gene expression (Lamont et al. 2005; Wang et al. 2009; Li et al. 2013) with the hippocampal circadian gene expression anti-phasic for the diurnal grass rat and nocturnal rodents (Ramanathan et al. 2010; Martin-Fairey and Nunez 2014). Phase differences in gene expression also occur in brain regions downstream from the SCN for diurnal versus nocturnal Degus (Otalora et al. 2013). Potentially, phase-specific coordination of physiological processes occurs locally in the brain regions generating or regulating those behaviors. Indeed, analysis of hippocampal circadian gene and protein expression reveals cyclic coordination of gene expression suggesting that hippocampal gene expression may form a temporal framework for memory formation (Jilg et al. 2010; Rawashdeh et al. 2014). In a mouse model used to represent evening-type individuals, the clock mutation in a $\mathrm{Jcl} / \mathrm{ICR}$ background, in which the animals have long periods and 
phase delays, the animals demonstrate an impaired learning ability in the Morris water maze during the early dark phase (morning for the mice) along with damped hippocampal acetylcholine release (Sei et al. 2003, 2006).

In contrast, peak short and long-term olfactory memory in Drosophila occurs in the early to mid-night seemingly out of phase with the crepuscular activity of these insects (Lyons and Roman 2009; Fropf et al. 2014). Although the peak performance in olfactory memory is not dependent upon rhythms in olfactory sensitivity (Krishnan et al. 1999; Lyons and Roman 2009), the phase regulation of olfactory memory may be coordinated with olfactory-dependent behaviors such as courtship or predator avoidance. Mice exhibit peak recall for contextual fear conditioning in the early morning hours normally associated with periods of rest (Chaudhury and Colwell 2002). Increased memory for aversive stimuli may be coordinated with increased defensive behavioral responses when the animal is more vulnerable to predation and settling into its rest period. For example, ducks demonstrate vigilance during sleep to reduce predation risk (Zimmer et al. 2011). In humans, the circadian system increases arousal toward the late afternoon/early evening counteracting the homeostatic drive for sleep (Wright et al. 2012). Thus, variance of circadian regulation of memory between learning paradigms or in a species' restricted manner may be dependent upon intertwined metabolic processes or related behaviors.

Circadian peaks and troughs in memory and performance may represent separate functions of circadian regulation. Suppression of memory formation during specific phases may have evolved in conjunction with energy conservation. Neuronal activities and memory formation are metabolically expensive with the brain consuming $\sim 20 \%$ of an organism's total energy budget (for review, see Harris et al. 2012). The higher cost of synaptic plasticity can be observed in Drosophila in which an inverse relationship between longevity and improvements in memory and performance has been shown (Burger et al. 2008; Lagasse et al. 2012). Memory formation also decreases stress resistance (Mery and Kawecki 2005) and longevity is significantly decreased when long-term memory formation is forced on flies under starvation stress (Plaçais and Preat 2013).

\section{Mechanisms linking the circadian clock and memory}

At a circuit level, circadian modulation of memory processes could arise from rhythmic changes in synaptic connections, synapse number, or structure. Circadian changes in synapse number have been observed at Drosophila neuromuscular junctions along with circadian changes in motor neuron morphology (Mehnert and Cantera 2011; Ruiz et al. 2013). Dendrite length also is circadianly regulated in the optic lobe with larger dendritic trees observed early in the (subjective) day (Weber et al. 2009; Damulewicz and Pyza 2011). Notably for the regulation of output processes, the small ventral lateral circadian pacemaker neurons of Drosophila form differential synaptic contacts dependent upon the time of day (Fernández et al. 2008; Gorostiza et al. 2014). Rhythmic axonal remodeling occurs through matrix metalloproteinase regulation of the circadian neurotransmitter PDF (Depetris-Chauvin et al. 2014), presumably due to the circadian regulation of matrix metalloproteinases (Kadener et al. 2007; Nagoshi et al. 2010). Thus, circadian regulation of neuronal connections as well as the strength of synaptic contacts represent likely mechanisms through which circadian pacemaker neurons could coordinate different physiological and behavioral processes across the day and night.

In vertebrate models, in vivo circadian regulation of synaptic morphology has been studied using the transparent zebrafish lar- vae (Appelbaum et al. 2010; Elbaz et al. 2013). Researchers found the greatest number of synaptic boutons for hypocretin neurons projecting to the pineal gland observed during the (subjective) day with an oppositely phased rhythm observed for hypocretin neurons projecting to the hindbrain (Appelbaum et al. 2010). In Siberian hamsters, diurnal rhythms in dendritic spine density occur with opposite phases in the hippocampal CA1 and the dentate gyrus (Ikeno et al. 2013). Antiphase circadian regulation of neuronal projections supports the hypothesis that local brain regions regulate rhythmicity of behaviors and processes specific to that region.

The circadian clock could regulate learning and memory at a circuit level through hormonal signaling. Melatonin, a circulating hormone rhythmically secreted by the pineal gland, functions in the circadian system through the SCN and also functions in neural plasticity (for review, see Rawashdeh and Maronde 2012). In pharmacological studies, acute administration of melatonin inhibits long-term potentiation (Wang et al. 2005) and affects hippocampal neuronal plasticity (El-Sherif et al. 2002, 2003); whereas melatonin receptor antagonists phase-specifically enhance nighttime memory in diurnal animals (Rawashdeh et al. 2007). In rats, melatonin phase-specifically enhances memory during the day and impairs memory at night (Takahashi et al. 2013). In mice with genetic deletions of both high-affinity G-protein coupled melatonin receptors $\left(\mathrm{MT}_{1}^{-/-} ; \mathrm{MT}_{2}^{-/-}\right)$, animals exhibit enhanced cognitive performance ( $\mathrm{O}^{\prime}$ Neal-Moffitt et al. 2014). However, the action of melatonin on cognitive performance may vary between $\mathrm{MT}_{1}$ and $\mathrm{MT}_{2}$ signaling as a $\mathrm{MT}_{2}$ receptor deletion results in impairments in hippocampal long-term memory (Larson et al. 2006). In Alzheimer's disease models, melatonin or $\mathrm{MT}_{2}$ agonists appear to have a therapeutic effect on cognitive performance and hippocampal neuroplasticity (Bahna et al. 2014; Ali and Kim 2015; Stefanova et al. 2015). While melatonin has the potential to link the circadian system with memory and performance, the actions of melatonin may vary with circadian phase, task specificity, or receptor signaling.

Glucocorticoids promote synaptic development, neuronal plasticity (Liston and Gan 2011), and cell proliferation, and themselves have the capacity for resetting circadian oscillators in peripheral tissues (Balsalobre et al. 2000a; Dickmeis and Foulkes 2011). Diurnal release of glucocorticoids occurs in synchrony with the animal's activity cycle (Dickmeis and Foulkes 2011). In mice, training during peak glucocorticoid levels increases learning-induced spine formation, while training during the circadian trough does not (Liston et al. 2013). Furthermore, disruption of glucocorticoid cycling following learning by increasing trough glucocorticoid levels reduces survival of learning-induced spines and impairs long-term memory (Liston et al. 2013). Prolonged increases in glucocorticoid levels mediate, at least in part, the effects of chronic jet lag on decreased neurogenesis in rodent models (Gibson et al. 2010) and temporal lobe atrophy in humans (Cho 2001). Chronic exposure to high levels of glucocorticoids disrupts previous memories and eliminates new spines induced by learning as well as previously present spines (Liston et al. 2013). Thus, rhythmic regulation of stress hormones alters the efficacy of learning-induced synaptogenesis and is necessary for long-term synaptic stability and robust memories.

Circadian suppression of memory at night also may result from synaptic scaling during rest periods. The synaptic homeostasis hypothesis of sleep emphasizes physical changes in synaptic structure that occur during sleep permitting decreased energy consumption and restoration of cellular homeostasis (for review, see Tononi and Cirelli 2014). Structural evidence for synaptic scaling comes from Drosophila in which decreased synapse number and size may be observed after sleep (Bushey et al. 2011). Widespread long-term memory formation accompanied by 
synaptic strengthening and morphological changes during normally inactive periods could be counterproductive to sleep and rest homeostatic functions.

At the molecular level, circadian modulation of memory could occur at multiple levels through regulation of sensory gating, neurotransmission, kinase signaling cascades, macromolecular synthesis, or epigenetic modifications. Circadian gating of sensory processes, as observed for olfaction in insects (Krishnan et al. 1999) and mammals (Granados-Fuentes et al. 2006; Miller et al. 2014), could alter salience and perception of sensory stimuli resulting in differential learning acquisition. Downstream, molecular processes can serve as a bridge between the circadian clock and memory either through circadian regulation of basal expression and activity levels, rhythms in cellular compartmentalization, or rhythms in training-inducible activity or expression (Table 1). Neurotransmitters with circadian rhythms in basal expression and activity in brain regions associated with memory formation include acetylcholine, nitric oxide, serotonin, and GABA. Neurotransmitters can also function in conveyance of temporal information in memory context as suggested for acetylcholine in time-stamping (Hut and Van der Zee 2011) and GABA synthesis in fear memory (Bergado-Acosta et al. 2014). An example of circadian regulation of training-induced neurotransmitter release comes from Aplysia, in which sensitization training-induced serotonin release is circadianly regulated with higher levels of serotonin observed in the hemolymph following training during the subjective day (Lyons et al. 2006). Circadian regulation of inhibitory pathways may also modulate memory processes. In rats, disinhibition of recurrent GABAergic inhibition is suggested as a mechanism for regulating circadian rhythmicity of LTP in hippocampal CA1 (Nakatsuka and Natsume 2014). In hamsters, circadian rhythmicity is necessary for declarative learning and memory as increased SCN GABAergic inhibition to the hippocampus in arrhythmic animals impairs memory (Ruby et al. 2008, 2013; Fernandez et al. 2014).

The phylogenetically conserved mechanisms of memory formation include intracellular second messenger and kinase signaling pathways. The MAPK/ERK signaling cascade comprises a necessary component of nonassociative (Sharma et al. 2003; for review, see Hawkins and Byrne 2015) and associative learning paradigms in invertebrate models (Michel et al. 2011), and associative memory such as contextual fear conditioning in vertebrates (Atkins et al. 1998). In the hippocampus, circadian cycling of phospho-ERK with peaks during the subjective day promotes memory formation and persistence of long-term memory (Eckel-Mahan et al. 2008; Eckel-Mahan 2012). Although a basal circadian rhythm in phospho-MAPK is not observed in Aplysia ganglia, sensitization training during the (subjective) day induces significantly greater MAPK activity compared with training during the night (Lyons et al. 2006). Potentially, second messengerdependent kinase pathways such as the cAMP/PKA pathway may also transduce circadian signals in learning acquisition or memory formation. Diurnal rhythms in cAMP levels, presumably due to adenylyl cyclase activity, occur in the hippocampus with peak levels during the day (Eckel-Mahan et al. 2008). Hippocampal rhythms in adenylyl cyclase and ERK activity are dependent upon SCN rhythms as SCN ablation abolishes these rhythms and impairs spatial memory persistence (Phan et al. 2011).

Table 1. Examples of molecular interactions between circadian systems and learning and memory

\begin{tabular}{|c|c|c|c|}
\hline & Model system & Type of interaction & References \\
\hline \multicolumn{4}{|l|}{ Neurotransmitters } \\
\hline \multirow[t]{2}{*}{ Acetylcholine } & Rats & May convey time-stamp information from the SCN & Hut and Van der Zee (2011) \\
\hline & Rhesus Monkeys & $\begin{array}{l}\text { Muscarinic receptors associated with diurnal rhythms in } \\
\text { spatial learning }\end{array}$ & Haley et al. (2011) \\
\hline \multirow[t]{2}{*}{ GABA } & $\begin{array}{l}\text { Golden } \\
\text { Hamsters }\end{array}$ & $\begin{array}{l}\text { GABA }_{A} \text { Receptor-basal circadian rhythm in cerebral cortex } \\
\text { GABA output from SCN to hippocampus regulates rhythms } \\
\text { in spatial learning; inhibits learning in arrhythmic animals }\end{array}$ & $\begin{array}{l}\text { Kanterewicz et al. (1995); Ruby et al. } \\
(2008,2013)\end{array}$ \\
\hline & Mice & $\begin{array}{l}\text { GAD } 65 \text { dependent GABA synthesis implicated in } \\
\text { phase-specific learning }\end{array}$ & Bergado-Acosta et al. (2014) \\
\hline Nitric oxide & Manduca sexta & $\begin{array}{l}\text { Inhibition of nitric oxide phase specifically inhibits short } \\
\text { and intermediate-term memory }\end{array}$ & Gage and Nighorn (2014) \\
\hline Serotonin & Aplysia & Circadian modulation of training-induced release & Lyons et al. (2006) \\
\hline \multicolumn{4}{|c|}{ Second Messengers and Signaling Pathways } \\
\hline $\begin{array}{l}\text { CAMP/adenylyl } \\
\text { cyclase }\end{array}$ & Mice & $\begin{array}{l}\text { Rhythms in hippocampus, dependent on SCN; necessary } \\
\text { for LTM formation and maintenance }\end{array}$ & $\begin{array}{l}\text { (Eckel-Mahan et al. 2008; Phan et al. } \\
\text { 2011) }\end{array}$ \\
\hline \multirow[t]{2}{*}{ MAPK } & Aplysia & Phase-specific activation after training & (Lyons et al. 2006) \\
\hline & Mice & $\begin{array}{l}\text { Rhythms in hippocampus; necessary for LTM formation and } \\
\text { persistence }\end{array}$ & $\begin{array}{l}\text { Eckel-Mahan et al. (2008); Phan et al. } \\
\text { (2011); Wardlaw et al. (2014) }\end{array}$ \\
\hline PKA & Mice & Activity rhythms in hippocampus; absent in per1 mutants & Rawashdeh et al. (2014) \\
\hline Phosphatases & Aplysia & Circadian phase-specific inhibition of ITM & Michel et al. (2013) \\
\hline \multicolumn{4}{|c|}{ Transcription factors and epigenetic changes } \\
\hline \multirow[t]{3}{*}{ CREB } & Drosophila & $\begin{array}{l}\text { Diurnal rhythms in Mushroom Bodies; may underlie } \\
\text { rhythms in olfactory memory }\end{array}$ & Fropf et al. (2014) \\
\hline & Rats & Diurnal phosphorylation in hippocampus & Hsieh et al. (2015) \\
\hline & Mice & Hippocampal rhythms in phosphorylation & $\begin{array}{l}\text { Eckel-Mahan et al. (2008); Rawashdeh } \\
\text { et al. (2014) }\end{array}$ \\
\hline C/EBP & Aplysia & Phase specifically increased after training & Lyons et al. (2006) \\
\hline $\begin{array}{l}\text { Acetylation/ } \\
\text { methylation of } \mathrm{H} 3\end{array}$ & Mice & $\begin{array}{l}\text { Basal rhythms in histone markers; learning-induction phase } \\
\text { specific and absent in per1 mutants }\end{array}$ & Rawashdeh et al. (2014) \\
\hline \multicolumn{4}{|l|}{ Hormones } \\
\hline Cortisol & Mice & $\begin{array}{l}\text { Diurnal rhythms; peaks promote dendritic spine formation } \\
\text { after learning; troughs promote dendritic spine } \\
\text { maintenance. }\end{array}$ & Liston et al. (2013) \\
\hline Melatonin & Danio rerio, Rats & Diurnal rhythm; circadian phase-specific learning. & $\begin{array}{l}\text { Rawashdeh et al. (2007); Rawashdeh and } \\
\text { Maronde (2012); Takahashi et al. (2013) }\end{array}$ \\
\hline
\end{tabular}


Conversely, circadian regulation of memory may also occur through protein phosphatase activity. In Aplysia, inhibition of protein phosphatases rescues the induction of intermediateterm memory during the late subjective day and night (Michel et al. 2013). In mammals, Suprachiasmatic Oscillatory Protein (SCOP), an oscillatory protein first identified in the SCN, is a serine/threonine phosphatase enriched in the hippocampus (Shimizu et al. 2010) that is regulated by calpain-dependent protein degradation (Shimizu et al. 2007). SCOP suppresses the ERK pathway through its binding to Ras (Shimizu et al. 2003, 2007, 2010; Gao et al. 2005). Through its protein phosphatase activity, SCOP also regulates AKT pathway activation in the hippocampus (Jackson et al. 2010). Thus, the circadian regulation of intracellular signaling cascades through kinase and phosphatase regulation provides broad mechanisms through which the circadian clock can impact multiple types of learning and memory.

The induction of gene expression, a necessary occurrence for LTM, provides multiple junctures through which the circadian clock can regulate memory formation. Rhythmic oscillations in pERK or CAMP/PKA pathways provide a mechanism for circadian regulation of learning-induced gene transcription through the transcription factor CREB (cAMP element response binding protein). In the hippocampus, phospho-CREB levels oscillate in phase with the pERK and cAMP (Eckel-Mahan et al. 2008). More recently, hippocampal circadian rhythms in CREB activation have been shown to be dependent upon the Period1 gene (Rawashdeh et al. 2014). In Aplysia, training animals during the subjective day results in significantly increased protein levels of the CREBdependent immediate early gene $A p C / E B P$ (Lyons et al. 2006), a transcription factor in nonassociative (Alberini et al. 1994), and associative memory formation (Levitan et al. 2008). In Drosophila mushroom bodies, a region necessary for many forms of memory, dCREB2 exhibits circadian oscillations in gene expression, nuclear protein levels and activity, likely mediating rhythms in LTM formation (Tanenhaus et al. 2012; Fropf et al. 2014).

Recent studies have highlighted the role of epigenetic modifications affecting gene transcription in the circadian regulation of memory formation. Acetylation of histone protein, particularly $\mathrm{H} 3$, enhances the induction and formation of long-term memory (Levenson et al. 2004), while trimethylation of $\mathrm{H} 3$ at lysine 4 marks active transcription (Gupta et al. 2010). The circadian clock regulates $\mathrm{H} 3$ acetylation at lysine 14 in phase with trimethylation of $\mathrm{H3}$ at lysine 4 providing a mechanism for circadian regulation of learning-induced gene transcription (Rawashdeh et al. 2014). SIRT1, a NAD-dependent deacetylase, which regulates CLOCK mediated chromatin remodeling and circadian rhythms (Asher et al. 2008; Nakahata et al. 2008) also functions in learning and memory (Gao et al. 2010). SIRT1 oscillates in the hippocampus with alterations in SIRT1 rhythm resulting in memory deficits (Rawashdeh et al. 2014). Thus, circadian regulation of learninginduced transcription necessary for LTM through epigenetic mechanisms or transcription factor activation provides a key mechanism through which the circadian clock targets memory formation. The identification of modulated steps and targets of the circadian clock potentially may serve as the foundation for future therapies to improve memory and performance.

\section{Countermeasures for circadian desynchrony}

Circadian modulation of human performance results in high economic costs to businesses attributable to industrial and occupational accidents, decreased worker productivity, and increased health costs for employees (Rajaratnam et al. 2013; Wright et al. 2013) besides posing a serious health risk to individuals when shift work induces circadian misalignment. Moreover, technolog- ical advances have resulted in increased human exposure to artificial light at night, particularly blue wavelengths that most affect the circadian clock, compounding the problems of circadian disorders in modern society (for review, see Bonmati-Carrion et al. 2014; Stevens and Zhu 2015). Consequently, identifying methods to maintain circadian rhythms or minimize circadian misalignment are necessary both at home and the workplace.

Recommendations by the American Academy of Sleep Medicine to ameliorate the problems of shift work are designed to minimize individual circadian misalignment and to increase alertness and performance (Morgenthaler et al. 2007). In brief review, these strategies include: (1) the use of bright light therapy to enhance circadian re-entrainment (Burgess et al. 2002; Gooley 2008; Dodson and Zee 2010) combined with morning light restriction through the use of dark goggles to improve circadian adaptation (Crowley et al. 2003; Smith et al. 2009; Sasseville and Hébert 2010; Boivin et al. 2012). (2) Scheduled napping to counter fatigue and sleepiness during night shifts (Purnell et al. 2002; Schweitzer et al. 2006), although sleep inertia upon awakening may induce cognitive impairments (Wertz et al. 2006; Signal et al. 2013). (3) Melatonin administration to promote daytime sleep. Readily passing through the blood brain barrier, melatonin increases daytime sleep duration with little effect on sleep latency for night-shift workers (Sharkey et al. 2001; Liira et al. 2015) and phase-shifts circadian rhythms in simulated night-shift studies (Sharkey and Eastman 2002). During the day, the circadian system maintains arousal in the face of increased time awake with decreased arousal at night due, in part, to rising melatonin levels which target $\mathrm{MT}_{1}$ and $\mathrm{MT}_{2}$ receptors in the SCN to dampen SCN driven arousal signals (Dodson and Zee 2010; Carocci et al. 2014). Melatonin is used as a treatment of circadian perturbations including jet lag, shift work, or delayed sleep disorder (PandiPerumal et al. 2008; Brown et al. 2009; Srinivasan et al. 2010) and can be used in combination with bright light therapy, to accelerate reentrainment for jet lag (Dodson and Zee 2010; Zee and Goldstein 2010). Newly developed selective $\mathrm{MT}_{1} / \mathrm{MT}_{2}$ receptor agonists (Srinivasan et al. 2010; Carocci et al. 2014) include Ramelteon which effectively acts as a phase shifting agent in humans (Richardson et al. 2008; Carocci et al. 2014) and animal models (Rawashdeh et al. 2011) as well as Tasimelteon which facilitates entrainment to a 24 -h cycle maintaining melatonin rhythms, sleep latency, and sleep quality (Carocci et al. 2014; Neubauer 2015). (4) The use of wakefulness promoting drugs to increase arousal and performance in circadian disorders include caffeine and modafinil. In forced desynchrony studies, repeated low doses of caffeine counteracted homeostatic sleep pressures, enhanced alertness, and ameliorated reductions in cognitive performance, particularly at the circadian troughs of performance (Walsh et al. 1990; Wyatt et al. 2004; Schweitzer et al. 2006). Modafinil and its $R$-enantiomer armodafinil improve attention and alertness, cognitive performance, long-term memory, and reduce sleepiness associated with night-shift work (Walsh et al. 2004; Czeisler et al. 2005, 2009; Grady et al. 2010; Roth 2012; Liira et al. 2014, 2015) with little effect on sleep efficiency, quantity, or quality following shift work (Walsh et al. 2004; Czeisler et al. 2005; Grady et al. 2010). In addition to the above strategies designed to enable permanent shift workers to maintain regular rhythms minimizing circadian misalignment and enhancing performance, exercise during a night shift also may facilitate phase shifting and maintenance of circadian rhythms (Eastman et al. 1995; Barger et al. 2004). For further review of strategies for managing shift work, see Boivin and James (2005), Morgenthaler et al. (2007) and Boivin and Boudreau (2014).

For individuals engaged in rotating shift work given the length of time necessary for complete resynchronization of central and peripheral oscillators, reentrainment to the work cycle 
may not be optimal. For these individuals, managing the direction of the rotation may reduce some negative health effects associated with shift work or even maintaining entrainment to a daytime light dark cycle through minimizing the effects of workplace lighting at night on melatonin secretion and hormonal rhythms. Recent research has suggested that the wearing of glasses with optical filters to block wavelengths shorter than 480 or 500 $\mathrm{nm}$ may attenuate circadian misalignment, improve mood disorders, enhance cognitive performance during shift work, and sleep upon cessation of shift work (Rahman et al. 2013; Casper and Rahman 2014). New applications and software also are becoming available to provide optical filters for personal electronic devices and home computers to minimize circadian perturbations from electronic devices during evening use. The realities of technological advancements in a modern, global society, and the risks to individual and public health due to circadian modulation of cognitive function or circadian desynchronization, emphasize the critical need for continued research to understand the molecular mechanisms underlying circadian and memory interactions, developing new therapeutic treatments and identifying practical measures to minimize individual circadian stresses.

\section{Acknowledgments}

We thank Dr. Gregg Roman for helpful discussions and Miguel de la Flor for the brain illustration in Figure 1. Research support for L.C.L. provided by National Institute on Alcohol Abuse and Alcoholism grant R21AA021233 and National Institute of Neurological Disorders and Stroke grant R21NS088835.

\section{References}

Abraham U, Prior JL, Granados-Fuentes D, Piwnica-Worms DR, Herzog ED. 2005. Independent circadian oscillations of Period1 in specific brain areas in vivo and in vitro. J Neurosci 25: $8620-8626$.

Alberini CM, Ghirardi M, Metz R, Kandel ER. 1994. C/EBP is an immediate-early gene required for the consolidation of long-term facilitation in Aplysia. Cell 76: 1099-1114.

Ali T, Kim MO. 2015. Melatonin ameliorates amyloid $\beta$-induced memory deficits, tau hyperphosphorylation and neurodegeneration via PI3 Akt/GSk3 $\beta$ pathway in the mouse hippocampus. J Pineal Res doi: 10.1111/jpi.12238

Alterman T, Luckhaupt SE, Dahlhamer JM, Ward BW, Calvert GM. 2013. Prevalence rates of work organization characteristics among workers in the U.S.: data from the 2010 National Health Interview Survey. Am J Ind Med 56: 647-659.

Appelbaum L, Wang G, Yokogawa T, Skariah GM, Smith SJ, Mourrain P, Mignot E. 2010. Circadian and homeostatic regulation of structural synaptic plasticity in hypocretin neurons. Neuron 68: 87-98.

Aragona BJ, Curtis JT, Davidson AJ, Wang Z, Stephan FK. 2002. Behavioral and neurochemical investigation of circadian time-place learning in the rat. J Biol Rhythms 17: 330-344.

Arble DM, Ramsey KM, Bass J, Turek FW. 2010. Circadian disruption and metabolic disease: findings from animal models. Best Pract Res Clin Endocrinol Metab 24: 785-800.

Asher G, Gatfield D, Stratmann M, Reinke H, Dibner C, Kreppel F, Mostoslavsky R, Alt FW, Schibler U. 2008. SIRT1 regulates circadian clock gene expression through PER2 deacetylation. Cell 134: 317-328.

Atkins CM, Selcher JC, Petraitis JJ, Trzaskos JM, Sweatt JD. 1998. The MAPK cascade is required for mammalian associative learning. Nat Neurosci 1: $602-609$

Aton SJ, Colwell CS, Harmar AJ, Waschek J, Herzog ED. 2005. Vasoactive intestinal polypeptide mediates circadian rhythmicity and synchrony in mammalian clock neurons. Nat Neurosci 8: 476-483.

Bahna SG, Sathiyapalan A, Foster JA, Niles LP. 2014. Regional upregulation of hippocampal melatonin MT2 receptors by valproic acid: therapeutic implications for Alzheimer's disease. Neurosci Lett 576: 84-87.

Balsalobre A, Brown SA, Marcacci L, Tronche F, Kellendonk C, Reichardt HM, Schütz G, Schibler U. 2000a. Resetting of circadian time in peripheral tissues by glucocorticoid signaling. Science 289: $2344-2347$

Balsalobre A, Marcacci L, Schibler U. 2000b. Multiple signaling pathways elicit circadian gene expression in cultured Rat-1 fibroblasts. Curr Biol 10: $1291-1294$.
Barger LK, Wright KP Jr, Hughes RJ, Czeisler CA. 2004. Daily exercise facilitates phase delays of circadian melatonin rhythm in very dim light. Am J Physiol Regul Integr Physiol 286(6): R1077-R1084.

Barnard AR, Nolan PM. 2008. When clocks go bad: neurobehavioural consequences of disrupted circadian timing. PLoS Genet 4: e1000040.

Bass J, Takahashi JS. 2010. Circadian integration of metabolism and energetics. Science 330: 1349-1354.

Bergado-Acosta JR, Müller I, Richter-Levin G, Stork O. 2014. The GABA-synthetic enzyme GAD65 controls circadian activation of conditioned fear pathways. Behav Brain Res 260: 92-100.

Berry JA, Davis RL. 2014. Active forgetting of olfactory memories in Drosophila. Prog Brain Res 208: 39-62.

Biebach H, Falk H, Krebs JR. 1991. The effect of constant light and phase shifts on a learned time-place association in garden warblers (Sylvia borin): hourglass or circadian clock? J Biol Rhythms 6: 353-365.

Boivin DB, Boudreau P. 2014. Impacts of shift work on sleep and circadian rhythms. Pathol Biol (Paris) 62: 292-301.

Boivin DB, James FO. 2005. Light treatment and circadian adaptation to shift work. Ind Health 43: 34-48.

Boivin DB, Boudreau P, Tremblay GM. 2012. Phototherapy and orange-tinted goggles for night-shift adaptation of police officers on patrol. Chronobiol Int 29: 629-640.

Bonmati-Carrion MA, Arguelles-Prieto R, Martinez-Madrid MJ, Reiter R, Hardeland R, Rol MA, Madrid JA. 2014. Protecting the melatonin rhythm through circadian healthy light exposure. Int J Mol Sci 15: 23448-23500.

Brown GM, Pandi-Perumal SR, Trakht I, Cardinali DP. 2009. Melatonin and its relevance to jet lag. Travel Med Infect Dis 7: 69-81.

Buhr ED, Takahashi JS. 2013. Molecular components of the mammalian circadian clock. Handb Exp Pharmacol 217: 3-27.

Burger JM, Kolss M, Pont J, Kawecki TJ. 2008. Learning ability and longevity: a symmetrical evolutionary trade-off in Drosophila. Evolution 62: $1294-1304$.

Burgess HJ, Sharkey KM, Eastman CI. 2002. Bright light, dark and melatonin can promote circadian adaptation in night shift workers. Sleep Med Rev 6: 407-420.

Bushey D, Tononi G, Cirelli C. 2011. Sleep and synaptic homeostasis: structural evidence in Drosophila. Science 332: 1576-1581.

Cain SW, Ralph MR. 2009. Circadian modulation of conditioned place avoidance in hamsters does not require the suprachiasmatic nucleus. Neurobiol Learn Mem 91: 81-84.

Cain SW, Chou T, Ralph MR. 2004. Circadian modulation of performance on an aversion-based place learning task in hamsters. Behav Brain Res 150: 201-205.

Cain SW, McDonald RJ, Ralph MR. 2008. Time stamp in conditioned place avoidance can be set to different circadian phases. Neurobiol Learn Mem 89: $591-594$

Cain SW, Yoon J, Shrestha TC, Ralph MR. 2014. Retention of a 24-hour time memory in Syrian hamsters carrying the 20-hour short circadian

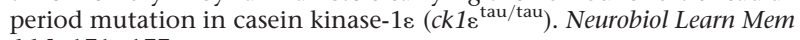
114: $171-177$.

Cajochen C, Münch M, Knoblauch V, Blatter K, Wirz-Justice A. 2006. Age-related changes in the circadian and homeostatic regulation of human sleep. Chronobiol Int 23: 461-474.

Carocci A, Catalano A, Sinicropi MS. 2014. Melatonergic drugs in development. Clin Pharmacol 6: 127-137.

Casper RF, Rahman S. 2014. Spectral modulation of light wavelengths using optical filters: effect on melatonin secretion. Fertil Steril 102: 336-338.

Cermakian N, Lamont EW, Boudreau P, Boivin DB. 2011. Circadian clock gene expression in brain regions of Alzheimer's disease patients and control subjects. J Biol Rhythms 26: 160-170.

Chaudhury D, Colwell CS. 2002. Circadian modulation of learning and memory in fear-conditioned mice. Behav Brain Res 133: 95-108.

Chaudhury D, Wang LM, Colwell CS. 2005. Circadian regulation of hippocampal long-term potentiation. J Biol Rhythms 20: 225-236.

Cho K. 2001. Chronic 'jet lag' produces temporal lobe atrophy and spatial cognitive deficits. Nat Neurosci 4: 567-568.

Cho K, Ennaceur A, Cole JC, Suh CK. 2000. Chronic jet lag produces cognitive deficits. J Neurosci 20: RC66.

Cohen DA, Wang W, Wyatt JK, Kronauer RE, Dijk DJ, Czeisler CA, Klerman EB. 2010. Uncovering residual effects of chronic sleep loss on human performance. Sci Transl Med 2: 14ra3.

Crowley SJ, Lee C, Tseng CY, Fogg LF, Eastman CI. 2003. Combinations of bright light, scheduled dark, sunglasses, and melatonin to facilitate circadian entrainment to night shift work. J Biol Rhythms 18: 513-523.

Czeisler CA, Dijk DJ, Duffy JF. 1994. Entrained phase of the circadian pacemaker serves to stabilize alertness and performance throughout the habitual waking day. In Sleep onset: normal and abnormal processes (ed. Ogilvie RD, Harsh JR), pp. 89-110. American Psychological Association, Washington, DC.

Czeisler CA, Walsh JK, Roth T, Hughes RJ, Wright KP, Kingsbury L, Arora S, Schwartz JR, Niebler GE, Dinges DF, et al. 2005. Modafinil for excessive 
sleepiness associated with shift-work sleep disorder. N Engl J Med 353: 476-486.

Czeisler CA, Walsh JK, Wesnes KA, Arora S, Roth T. 2009. Armodafinil for treatment of excessive sleepiness associated with shift work disorder: a randomized controlled study. Mayo Clin Proc 84: 958-972.

Daan S, Pittendrigh CS. 1976. A functional analysis of circadian pacemakers in nocturnal rodents. I Comp Physiol 106: 253-266.

Damulewicz M, Pyza E. 2011. The clock input to the first optic neuropil of Drosophila melanogaster expressing neuronal circadian plasticity. PLoS One 6: e21258.

Davidson AJ, Sellix MT, Daniel J, Yamazaki S, Menaker M, Block GD. 2006. Chronic jet-lag increases mortality in aged mice. Curr Biol 16: R914-R916.

Davidson AJ, Yamazaki S, Arble DM, Menaker M, Block GD. 2008. Resetting of central and peripheral circadian oscillators in aged rats. Neurobiol Aging 29: 471-477.

Davidson AJ, Castanon-Cervantes O, Leise TL, Molyneux PC, Harrington ME. 2009. Visualizing jet lag in the mouse suprachiasmatic nucleus and peripheral circadian timing system. Eur J Neurosci 29: $171-180$.

Decker S, McConnaughey S, Page TL. 2007. Circadian regulation of insect olfactory learning. Proc Natl Acad Sci 104: 15905-15910.

Depetris-Chauvin A, Fernández-Gamba A, Gorostiza EA, Herrero A, Castaño EM, Ceriani MF. 2014. Mmp1 processing of the PDF neuropeptide regulates circadian structural plasticity of pacemaker neurons. PLoS Genet 10: e1004700.

Devan BD, Goad EH, Petri HL, Antoniadis EA, Hong NS, Ko CH, Leblanc L, Lebovic SS, Lo Q, Ralph MR, et al. 2001. Circadian phase-shifted rats show normal acquisition but impaired long-term retention of place information in the water task. Neurobiol Learn Mem 75: 51-62.

Dickmeis T, Foulkes NS. 2011. Glucocorticoids and circadian clock control of cell proliferation: at the interface between three dynamic systems. Mol Cell Endocrinol 331: 11-22.

Dodson ER, Zee PC. 2010. Therapeutics for circadian rhythm sleep disorders. Sleep Med Clin 5: 701-715.

Doherty CJ, Kay SA. 2010. Circadian control of global gene expression patterns. Annu Rev Genet 44: 419-444.

Duvall LB, Taghert PH. 2012. The circadian neuropeptide PDF signals preferentially through a specific adenylate cyclase isoform AC3 in M pacemakers of Drosophila. PLoS Biol 10: e1001337.

Eastman CI, Hoese EK, Youngstedt SD, Liu L. 1995. Phase-shifting human circadian rhythms with exercise during the night shift. Physiol Behav 58: $1287-1291$

Eckel-Mahan KL. 2012. Circadian oscillations within the hippocampus support memory formation and persistence. Front Mol Neurosci 5: 46.

Eckel-Mahan KL, Phan T, Han S, Wang H, Chan GC, Scheiner ZS, Storm DR. 2008. Circadian oscillation of hippocampal MAPK activity and cAMP: implications for memory persistence. Nat Neurosci 11: 1074-1082.

El-Sherif Y, Hogan MV, Tesoriero J, Wieraszko A. 2002. Factors regulating the influence of melatonin on hippocampal evoked potentials: comparative studies on different strains of mice. Brain Res $\mathbf{9 4 5}$ 191-201.

El-Sherif Y, Tesoriero J, Hogan MV, Wieraszko A. 2003. Melatonin regulates neuronal plasticity in the hippocampus. J Neurosci Res 72: 454-460.

Elbaz I, Foulkes NS, Gothilf Y, Appelbaum L. 2013. Circadian clocks, rhythmic synaptic plasticity and the sleep-wake cycle in zebrafish. Front Neural Circuits 7: 9

Evans JA, Davidson AJ. 2013. Health consequences of circadian disruption in humans and animal models. Prog Mol Biol Transl Sci 119: 283-323.

Evans JA, Leise TL, Castanon-Cervantes O, Davidson AJ. 2013. Dynamic interactions mediated by nonredundant signaling mechanisms couple circadian clock neurons. Neuron 80: 973-983.

Farajnia S, Michel S, Deboer T, vanderLeest HT, Houben T, Rohling JH, Ramkisoensing A, Yasenkov R, Meijer JH. 2012. Evidence for neuronal desynchrony in the aged suprachiasmatic nucleus clock. J Neurosci 32: $5891-5899$

Fekete M, van Ree JM, Niesink RJ, de Wied D. 1985. Disrupting circadian rhythms in rats induces retrograde amnesia. Physiol Behav 34: 883-887.

Fernandez RI, Lyons LC, Levenson J, Khabour O, Eskin A. 2003. Circadian modulation of long-term sensitization in Aplysia. Proc Natl Acad Sci 100: $14415-14420$

Fernández MP, Berni J, Ceriani MF. 2008. Circadian remodeling of neuronal circuits involved in rhythmic behavior. PLoS Biol 6: e69.

Fernandez F, Lu D, Ha P, Costacurta P, Chavez R, Heller HC, Ruby NF. 2014. Dysrhythmia in the suprachiasmatic nucleus inhibits memory processing. Science 346: 854-857.

Fropf R, Zhang J, Tanenhaus AK, Fropf WJ, Siefkes E, Yin JC. 2014. Time of day influences memory formation and dCREB2 proteins in Drosophila. Front Syst Neurosci 8: 43.

Fujioka A, Fujioka T, Tsuruta R, Izumi T, Kasaoka S, Maekawa T. 2011. Effects of a constant light environment on hippocampal neurogenesis and memory in mice. Neurosci Lett 488: 41-44.
Gage SL, Nighorn A. 2014. The role of nitric oxide in memory is modulated by diurnal time. Front Syst Neurosci 8: 59 .

Gao T, Furnari F, Newton AC. 2005. PHLPP: a phosphatase that directly dephosphorylates Akt, promotes apoptosis, and suppresses tumor growth. Mol Cell 18: 13-24.

Gao J, Wang WY, Mao YW, Gräff J, Guan JS, Pan L, Mak G, Kim D, Su SC, Tsai LH. 2010. A novel pathway regulates memory and plasticity via SIRT1 and miR-134. Nature 466: 1105-1109.

Garren MV, Sexauer SB, Page TL. 2013. Effect of circadian phase on memory acquisition and recall: operant conditioning vs. classical conditioning. PLoS One 8: e58693.

Gerstner JR, Lyons LC, Wright KP Jr, Loh DH, Rawashdeh O, Eckel-Mahan KL, Roman GW. 2009. Cycling behavior and memory formation. J Neurosci 29: 12824-12830.

Gibson EM, Wang C, Tjho S, Khattar N, Kriegsfeld LJ. 2010. Experimental 'jet lag' inhibits adult neurogenesis and produces long-term cognitive deficits in female hamsters. PLoS One 5: e15267.

Gooley JJ. 2008. Treatment of circadian rhythm sleep disorders with light. Ann Acad Med Singapore 37: 669-676.

Gorostiza EA, Depetris-Chauvin A, Frenkel L, Pírez N, Ceriani MF. 2014 Circadian pacemaker neurons change synaptic contacts across the day. Curr Biol 24: 2161-2167.

Grady S, Aeschbach D, Wright KP Jr, Czeisler CA. 2010. Effect of modafinil on impairments in neurobehavioral performance and learning associated with extended wakefulness and circadian misalignment. Neuropsychopharmacology 35: 1910-1920.

Granados-Fuentes D, Saxena MT, Prolo LM, Aton SJ, Herzog ED. 2004 Olfactory bulb neurons express functional, entrainable circadian rhythms. Eur J Neurosci 19: 898-906.

Granados-Fuentes D, Tseng A, Herzog ED. 2006. A circadian clock in the olfactory bulb controls olfactory responsivity. J Neurosci 26: 12219-12225.

Gritton HJ, Sutton BC, Martinez V, Sarter M, Lee TM. 2009. Interactions between cognition and circadian rhythms: attentional demands modify circadian entrainment. Behav Neurosci 123: 937-948.

Gritton HJ, Kantorowski A, Sarter M, Lee TM. 2012. Bidirectional interactions between circadian entrainment and cognitive performance. Learn Mem 19: 126-141.

Gritton HJ, Stasiak AM, Sarter M, Lee TM. 2013. Cognitive performance as a zeitgeber: cognitive oscillators and cholinergic modulation of the SCN entrain circadian rhythms. PLoS One 8: e56206.

Grosch JW, Caruso CC, Rosa RR, Sauter SL. 2006. Long hours of work in the U.S.: associations with demographic and organizational characteristics, psychosocial working conditions, and health. Am J Ind Med 49: 943-952.

Gupta S, Kim SY, Artis S, Molfese DL, Schumacher A, Sweatt JD, Paylor RE, Lubin FD. 2010. Histone methylation regulates memory formation. I Neurosci 30: 3589-3599.

Haley GE, Landauer N, Renner L, Weiss A, Hooper K, Urbanski HF, Kohama SG, Neuringer M, Raber J. 2009. Circadian activity associated with spatial learning and memory in aging rhesus monkeys. Exp Neurol 217: $55-62$.

Hardt O, Nader K, Nadel L. 2013. Decay happens: the role of active forgetting in memory. Trends Cogn Sci 17: 111-120.

Harrington M. 2010. Location, location, location: important for jet-lagged circadian loops. J Clin Invest 120: 2265-2267.

Harris JJ, Jolivet R, Attwell D. 2012. Synaptic energy use and supply. Neuron 75: $762-777$.

Hatfield CF, Herbert J, van Someren EJ, Hodges JR, Hastings MH. 2004. Disrupted daily activity/rest cycles in relation to daily cortisol rhythms of home-dwelling patients with early Alzheimer's dementia. Brain 127: 1061-1074.

Hauber W, Bareiss A. 2001. Facilitative effects of an adenosine $A_{1} / A_{2}$ receptor blockade on spatial memory performance of rats: selective enhancement of reference memory retention during the light period. Behav Brain Res 118: 43-52.

Hawkins RD, Byrne JH. 2015. Associative learning in invertebrates. Cold Spring Harb Perspect Biol 7: pii: a021709.

Hendricks JC, Lu S, Kume K, Yin JC, Yang Z, Sehgal A. 2003. Gender dimorphism in the role of cycle (BMAL1) in rest, rest regulation, and longevity in Drosophila melanogaster. J Biol Rhythms 18: 12-25.

Holloway FA, Wansley RA. 1973. Multiple retention deficits at periodic intervals after active and passive avoidance learning. Behav Biol 9 $1-14$.

Honma S, Ono D, Suzuki Y, Inagaki N, Yoshikawa T, Nakamura W, Honma K. 2012. Suprachiasmatic nucleus: cellular clocks and networks. Prog Brain Res 199: 129-141.

Hsieh CY, Hung CH, Lee YH, Wu ST, Hu CJ. 2015. Effects of Light-Dark Cycle on Hippocampal iNOS Expression and CREB Activation in Rats. Chin J Physiol 58: 19-26.

Hurd MW, Ralph MR. 1998. The significance of circadian organization for longevity in the golden hamster. J Biol Rhythms 13: 430-436. 
Hut RA, Van der Zee EA. 2011. The cholinergic system, circadian rhythmicity, and time memory. Behav Brain Res 221: 466-480.

Ikeno T, Weil ZM, Nelson RJ. 2013. Photoperiod affects the diurnal rhythm of hippocampal neuronal morphology of Siberian hamsters. Chronobiol Int 30: 1089-1100.

Jackson TC, Verrier JD, Semple-Rowland S, Kumar A, Foster TC. 2010. PHLPP1 splice variants differentially regulate AKT and PKC $\alpha$ signaling in hippocampal neurons: characterization of PHLPP proteins in the adult hippocampus. J Neurochem 115: 941-955.

Jilg A, Lesny S, Peruzki N, Schwegler H, Selbach O, Dehghani F, Stehle JH. 2010. Temporal dynamics of mouse hippocampal clock gene expression support memory processing. Hippocampus 20: 377-388.

Kadener S, Stoleru D, McDonald M, Nawathean P, Rosbash M. 2007. Clockwork Orange is a transcriptional repressor and a new Drosophila circadian pacemaker component. Genes Dev 21: 1675-1686.

Kanterewicz BI, Rosenstein RE, Golombek DA, Yannielli PC, Cardinali DP. 1995. Daily variations in GABA receptor function in Syrian hamster cerebral cortex. Neurosci Lett 200: 211-213.

Karatsoreos IN, Bhagat S, Bloss EB, Morrison JH, McEwen BS. 2011. Disruption of circadian clocks has ramifications for metabolism, brain, and behavior. Proc Natl Acad Sci 108: 1657-1662.

Keller SM. 2009. Effects of extended work shifts and shift work on patient safety, productivity, and employee health. AAOHN J 57: 497-502; quiz 503-504.

Kiessling S, Eichele G, Oster H. 2010. Adrenal glucocorticoids have a key role in circadian resynchronization in a mouse model of jet lag. J Clin Invest 120: 2600-2609.

Ko CH, McDonald RJ, Ralph MR. 2003. The suprachiasmatic nucleus is not required for temporal gating of performance on a reward-based learning and memory task. Biol Rhythm Res 34: 177-192.

Kondratova AA, Dubrovsky YV, Antoch MP, Kondratov RV. 2010. Circadian clock proteins control adaptation to novel environment and memory formation. Aging (Albany NY) 2: 285-297.

Kott J, Leach G, Yan L. 2012. Direction-dependent effects of chronic "jet-lag" on hippocampal neurogenesis. Neurosci Lett 515: 177-180.

Krishnan B, Dryer SE, Hardin PE. 1999. Circadian rhythms in olfactory responses of Drosophila melanogaster. Nature 400: 375-378.

Lagasse F, Moreno C, Preat T, Mery F. 2012. Functional and evolutionary trade-offs co-occur between two consolidated memory phases in Drosophila melanogaster. Proc Biol Sci 279: 4015-4023.

Lamont EW, Robinson B, Stewart J, Amir S. 2005. The central and basolateral nuclei of the amygdala exhibit opposite diurnal rhythms of expression of the clock protein Period2. Proc Natl Acad Sci 102: $4180-4184$

Larson J, Jessen RE, Uz T, Arslan AD, Kurtuncu M, Imbesi M, Manev H. 2006. Impaired hippocampal long-term potentiation in melatonin MT2 receptor-deficient mice. Neurosci Lett 393: 23-26.

Lee JH, Wang W, Silva EJ, Chang AM, Scheuermaier KD, Cain SW, Duffy JF. 2009. Neurobehavioral performance in young adults living on a 28 -h day for 6 weeks. Sleep 32: 905-913.

Lehmann M, Gustav D, Galizia CG. 2011. The early bee catches the flower-circadian rhythmicity influences learning performance in honey bees, Apis mellifera. Behav Ecol Sociobiol 65: 205-215.

Levenson JM, O'Riordan KJ, Brown KD, Trinh MA, Molfese DL, Sweatt JD. 2004. Regulation of histone acetylation during memory formation in the hippocampus. J Biol Chem 279: 40545-40559.

Levitan D, Lyons LC, Perelman A, Green CL, Motro B, Eskin A, Susswein AJ. 2008. Training with inedible food in Aplysia causes expression of C/EBP in the buccal but not cerebral ganglion. Learn Mem 15: 412-416.

Li JZ, Bunney BG, Meng F, Hagenauer MH, Walsh DM, Vawter MP, Evans SJ, Choudary PV, Cartagena P, Barchas JD, et al. 2013. Circadian patterns of gene expression in the human brain and disruption in major depressive disorder. Proc Natl Acad Sci 110: 9950-9955.

Liira J, Verbeek JH, Costa G, Driscoll TR, Sallinen M, Isotalo LK, Ruotsalainen JH. 2014. Pharmacological interventions for sleepiness and sleep disturbances caused by shift work. Cochrane Database Syst Rev 8: CD009776.

Liira J, Verbeek J, Ruotsalainen J. 2015. Pharmacological interventions for sleepiness and sleep disturbances caused by shift work. JAMA 313: 961-962.

Liston C, Gan WB. 2011. Glucocorticoids are critical regulators of dendritic spine development and plasticity in vivo. Proc Natl Acad Sci 108: $16074-16079$

Liston C, Cichon JM, Jeanneteau F, Jia Z, Chao MV, Gan WB. 2013. Circadian glucocorticoid oscillations promote learning-dependent synapse formation and maintenance. Nat Neurosci 16: 698-705.

Lockley SW, Arendt J, Skene DJ. 2007. Visual impairment and circadian rhythm disorders. Dialogues Clin Neurosci 9: 301-314.

Logan RW, Williams WP, McClung CA. 2014. Circadian rhythms and addiction: mechanistic insights and future directions. Behav Neurosci 128: $387-412$.
Loh DH, Navarro J, Hagopian A, Wang LM, Deboer T, Colwell CS. 2010. Rapid changes in the light/dark cycle disrupt memory of conditioned fear in mice. PLoS One 5: e12546.

Luckhaupt SE. 2012. Short sleep duration among workers-United States, 2010. MMWR Morb Mortal Wkly Rep 61: 281-285.

Lyons LC, Roman G. 2009. Circadian modulation of short-term memory in Drosophila. Learn Mem 16: 19-27.

Lyons LC, Rawashdeh O, Katzoff A, Susswein AJ, Eskin A. 2005. Circadian modulation of complex learning in diurnal and nocturnal Aplysia. Proc Natl Acad Sci 102: 12589-12594.

Lyons LC, Collado MS, Khabour O, Green CL, Eskin A. 2006. The circadian clock modulates core steps in long-term memory formation in Aplysia. J Neurosci 26: 8662-8671.

Lyons LC, Green CL, Eskin A. 2008. Intermediate-term memory is modulated by the circadian clock. J Biol Rhythms 23: 538-542.

Martin-Fairey CA, Nunez AA. 2014. Circadian modulation of memory and plasticity gene products in a diurnal species. Brain Res 1581: 30-39.

Marquié JC, Tucker P, Folkard S, Gentil C, Ansiau D. 2015. Chronic effects of shift work on cognition: findings from the VISAT longitudinal study. Occup Environ Med 72: 285-264.

Martino TA, Tata N, Belsham DD, Chalmers J, Straume M, Lee P, Pribiag H, Khaper N, Liu PP, Dawood F, et al. 2007. Disturbed diurnal rhythm alters gene expression and exacerbates cardiovascular disease with rescue by resynchronization. Hypertension 49: 1104-1113.

Maywood ES, Reddy AB, Wong GK, O’Neill JS, O'Brien JA, McMahon DG, Harmar AJ, Okamura H, Hastings MH. 2006. Synchronization and maintenance of timekeeping in suprachiasmatic circadian clock cells by neuropeptidergic signaling. Curr Biol 16: 599-605.

Maywood ES, Fraenkel E, McAllister CJ, Wood N, Reddy AB, Hastings MH, Morton AJ. 2010. Disruption of peripheral circadian timekeeping in a mouse model of Huntington's disease and its restoration by temporally scheduled feeding. J Neurosci 30: 10199-10204.

Maywood ES, Chesham JE, O JA, Hastings MH. 2011. A diversity of paracrine signals sustains molecular circadian cycling in suprachiasmatic nucleus circuits. Proc Natl Acad Sci 108: 14306-14311.

McClung CR. 2006. Plant circadian rhythms. Plant Cell 18: 792-803.

McDonald MJ, Rosbash M. 2001. Microarray analysis and organization of circadian gene expression in Drosophila. Cell 107: 567-578.

McMenamin TM. 2007. A time to work: recent trends in shift work and flexible schedules. In Monthly Labor Review, Vol. 130: pp. 3-15.

Mehnert KI, Cantera R. 2011. Circadian rhythms in the morphology of neurons in Drosophila. Cell Tissue Res 344: 381-389.

Meijman T, van der Meer O, van Dormolen M. 1993. The after-effects of night work on short-term memory performance. Ergonomics 36: 37-42.

Mery F, Kawecki TJ. 2005. A cost of long-term memory in Drosophila. Science 308: 1148.

Michel M, Green CL, Eskin A, Lyons LC. 2011. PKG-mediated MAPK signaling is necessary for long-term operant memory in Aplysia. Learn Mem 18: 108-117.

Michel M, Gardner JS, Green CL, Organ CL, Lyons LC. 2013. Protein phosphatase-dependent circadian regulation of intermediate-term associative memory. J Neurosci 33: 4605-4613.

Miller JE, Granados-Fuentes D, Wang T, Marpegan L, Holy TE, Herzog ED. 2014. Vasoactive intestinal polypeptide mediates circadian rhythms in mammalian olfactory bulb and olfaction. J Neurosci 34: 6040-6046.

Mistlberger RE. 2011. Neurobiology of food anticipatory circadian rhythms. Physiol Behav 104: 535-545.

Mistlberger RE, de Groot MH, Bossert JM, Marchant EG. 1996. Discrimination of circadian phase in intact and suprachiasmatic nuclei-ablated rats. Brain Res 739: 12-18.

Mohawk JA, Green CB, Takahashi JS. 2012. Central and peripheral circadian clocks in mammals. Annu Rev Neurosci 35: 445-462.

Monclaro AV, Sampaio AC, Ribeiro NB, Barros M. 2014. Time-of-day effect on a food-induced conditioned place preference task in monkeys. Behav Brain Res 259: 336-341.

Moore-Ede MC, Sulzman FM, Fuller CA. 1982. The clocks that time us: physiology of the circadian timing system. Harvard University Press, Cambridge.

Morgenthaler TI, Lee-Chiong T, Alessi C, Friedman L, Aurora RN, Boehlecke B, Brown T, Chesson AL, Kapur V, Maganti R, et al. 2007. Practice parameters for the clinical evaluation and treatment of circadian rhythm sleep disorders. an American Academy of Sleep Medicine report. Sleep 30: $1445-1459$.

Mulder C, Van Der Zee EA, Hut RA, Gerkema MP. 2013. Time-place learning and memory persist in mice lacking functional Per1 and Per2 clock genes. J Biol Rhythms 28: 367-379.

Musiek ES. 2015. Circadian clock disruption in neurodegenerative diseases: cause and effect? Front Pharmacol 6: 29.

Nagano M, Adachi A, Nakahama K, Nakamura T, Tamada M, Meyer-Bernstein E, Sehgal A, Shigeyoshi Y. 2003. An abrupt shift in the day/night cycle causes desynchrony in the mammalian circadian center. J Neurosci 23: 6141-6151. 
Nagoshi E, Sugino K, Kula E, Okazaki E, Tachibana T, Nelson S, Rosbash M. 2010. Dissecting differential gene expression within the circadian neuronal circuit of Drosophila. Nat Neurosci 13: 60-68.

Nakahata Y, Kaluzova M, Grimaldi B, Sahar S, Hirayama J, Chen D, Guarente LP, Sassone-Corsi P. 2008. The NAD ${ }^{+}$-dependent deacetylase SIRT1 modulates CLOCK-mediated chromatin remodeling and circadian control. Cell 134: 329-340.

Nakamura TJ, Nakamura W, Yamazaki S, Kudo T, Cutler T, Colwell CS, Block GD. 2011. Age-related decline in circadian output. J Neurosci 31: 10201-10205.

Nakatsuka H, Natsume K. 2014. Circadian rhythm modulates long-term potentiation induced at CA1 in rat hippocampal slices. Neurosci Res 80: $1-9$.

Neubauer DN. 2015. Tasimelteon for the treatment of non-24-hour sleep-wake disorder. Drugs Today (Barc) 51: 29-35.

Nieoullon A, Bentué-Ferrer D, Bordet R, Tsolaki M, Förstl H. 2008. Importance of circadian rhythmicity in the cholinergic treatment of Alzheimer's disease: focus on galantamine*. Curr Med Res Opin 24: $3357-3367$.

O'Neal-Moffitt G, Pilli J, Kumar SS, Olcese J. 2014. Genetic deletion of $\mathrm{MT}_{1} / \mathrm{MT}_{2}$ melatonin receptors enhances murine cognitive and motor performance. Neuroscience 277: 506-521.

Oosterman JM, van Someren EJ, Vogels RL, Van Harten B, Scherder EJ. 2009. Fragmentation of the rest-activity rhythm correlates with age-related cognitive deficits. J Sleep Res 18: 129-135.

Orozco-Solis R, Sassone-Corsi P. 2014. Epigenetic control and the circadian clock: linking metabolism to neuronal responses. Neuroscience 264: $76-87$.

Otalora BB, Hagenauer MH, Rol MA, Madrid JA, Lee TM. 2013. Period gene expression in the brain of a dual-phasing rodent, the Octodon degus. J Biol Rhythms 28: 249-261.

Pace-Schott EF, Spencer RM, Vijayakumar S, Ahmed NA, Verga PW, Orr SP, Pitman RK, Milad MR. 2013. Extinction of conditioned fear is better learned and recalled in the morning than in the evening. J Psychiatr Res 47: $1776-1784$.

Pallier PN, Morton AJ. 2009. Management of sleep/wake cycles improves cognitive function in a transgenic mouse model of Huntington's disease. Brain Res 1279: 90-98.

Pallier PN, Maywood ES, Zheng Z, Chesham JE, Inyushkin AN, Dyball R, Hastings MH, Morton AJ. 2007. Pharmacological imposition of sleep slows cognitive decline and reverses dysregulation of circadian gene expression in a transgenic mouse model of Huntington's disease. J Neurosci 27: 7869-7878.

Panda S, Antoch MP, Miller BH, Su AI, Schook AB, Straume M, Schultz PG, Kay SA, Takahashi JS, Hogenesch JB. 2002. Coordinated transcription of key pathways in the mouse by the circadian clock. Cell 109: 307-320.

Pandi-Perumal SR, Trakht I, Spence DW, Srinivasan V, Dagan Y, Cardinali DP. 2008. The roles of melatonin and light in the pathophysiology and treatment of circadian rhythm sleep disorders. Nat Clin Pract Neurol 4: 436-447.

Phan TX, Chan GC, Sindreu CB, Eckel-Mahan KL, Storm DR. 2011. The diurnal oscillation of MAP (mitogen-activated protein) kinase and adenylyl cyclase activities in the hippocampus depends on the suprachiasmatic nucleus. J Neurosci 31: 10640-10647.

Plaçais PY, Preat T. 2013. To favor survival under food shortage, the brain disables costly memory. Science 339: 440-442.

Plautz JD, Kaneko M, Hall JC, Kay SA. 1997. Independent photoreceptive circadian clocks throughout Drosophila. Science 278: 1632-1635.

Pluquet O, Dejeans N, Chevet E. 2014. Watching the clock: endoplasmic reticulum-mediated control of circadian rhythms in cancer. Ann Med 46: $233-243$.

Preuss F, Tang Y, Laposky AD, Arble D, Keshavarzian A, Turek FW. 2008. Adverse effects of chronic circadian desynchronization in animals in a "challenging" environment. Am J Physiol Regul Integr Comp Physiol 295: R2034-R2040.

Pulimeno P, Mannic T, Sage D, Giovannoni L, Salmon P, Lemeille S, Giry-Laterriere M, Unser M, Bosco D, Bauer C, et al. 2013. Autonomous and self-sustained circadian oscillators displayed in human islet cells. Diabetologia 56: 497-507.

Purnell MT, Feyer AM, Herbison GP. 2002. The impact of a nap opportunity during the night shift on the performance and alertness of 12-h shift workers. J Sleep Res 11: 219-227.

Rahman SA, Shapiro CM, Wang F, Ainlay H, Kazmi S, Brown TJ, Casper RF. 2013. Effects of filtering visual short wavelengths during nocturnal shiftwork on sleep and performance. Chronobiol Int 30: 951-962.

Rajaratnam SM, Howard ME, Grunstein RR. 2013. Sleep loss and circadian disruption in shift work: health burden and management. Med J Aust 199: $\mathrm{S} 11-\mathrm{S} 15$.

Ralph MR, Menaker M. 1988. A mutation of the circadian system in golden hamsters. Science 241: 1225-1227.
Ralph MR, Ko CH, Antoniadis EA, Seco P, Irani F, Presta C, McDonald RJ. 2002. The significance of circadian phase for performance on a reward-based learning task in hamsters. Behav Brain Res 136: 179-184.

Ramanathan C, Stowie A, Smale L, Nunez A. 2010. PER2 rhythms in the amygdala and bed nucleus of the stria terminalis of the diurnal grass rat (Arvicanthis niloticus). Neurosci Lett 473: 220-223.

Rawashdeh O, Maronde E. 2012. The hormonal Zeitgeber melatonin: role as a circadian modulator in memory processing. Front Mol Neurosci 5: 27.

Rawashdeh O, de Borsetti NH, Roman G, Cahill GM. 2007. Melatonin suppresses nighttime memory formation in zebrafish. Science 318: $1144-1146$.

Rawashdeh O, Hudson RL, Stepien I, Dubocovich ML. 2011. Circadian periods of sensitivity for ramelteon on the onset of running-wheel activity and the peak of suprachiasmatic nucleus neuronal firing rhythms in $\mathrm{C} 3 \mathrm{H} / \mathrm{HeN}$ mice. Chronobiol Int 28: 31-38.

Rawashdeh O, Jilg A, Jedlicka P, Slawska J, Thomas L, Saade A, Schwarzacher SW, Stehle JH. 2014. PERIOD1 coordinates hippocampal rhythms and memory processing with daytime. Hippocampus 24: $712-723$.

Refinetti R. 2014. Relationship between circadian period and body size in the tau-mutant golden hamster. Can J Physiol Pharmacol 92: 27-33.

Reid KJ, McGee-Koch LL, Zee PC. 2011. Cognition in circadian rhythm sleep disorders. Prog Brain Res 190: 3-20.

Renn SC, Park JH, Rosbash M, Hall JC, Taghert PH. 1999. A pdf neuropeptide gene mutation and ablation of PDF neurons each cause severe abnormalities of behavioral circadian rhythms in Drosophila. Cell 99: 791-802.

Richardson GS, Zee PC, Wang-Weigand S, Rodriguez L, Peng X. 2008. Circadian phase-shifting effects of repeated ramelteon administration in healthy adults. J Clin Sleep Med 4: 456-461.

Roenneberg T. 2013. Chronobiology: the human sleep project. Nature 498: $427-428$.

Roth T. 2012. Appropriate therapeutic selection for patients with shift work disorder. Sleep Med 13: 335-341.

Rouch I, Wild P, Ansiau D, Marquié JC. 2005. Shiftwork experience, age and cognitive performance. Ergonomics 48: 1282-1293.

Ruby NF, Hwang CE, Wessells C, Fernandez F, Zhang P, Sapolsky R, Heller HC. 2008. Hippocampal-dependent learning requires a functional circadian system. Proc Natl Acad Sci 105: 15593-15598.

Ruby NF, Fernandez F, Garrett A, Klima J, Zhang P, Sapolsky R, Heller HC. 2013. Spatial memory and long-term object recognition are impaired by circadian arrhythmia and restored by the GABAA Antagonist pentylenetetrazole. PLoS One 8: e72433.

Ruiz S, Ferreiro MJ, Menhert KI, Casanova G, Olivera A, Cantera R. 2013. Rhythmic changes in synapse numbers in Drosophila melanogaster motor terminals. PLoS One 8: e67161.

Saper CB, Fuller PM. 2007. Inducible clocks: living in an unpredictable world. Cold Spring Harb Symp Quant Biol 72: 543-550.

Sasseville A, Hébert M. 2010. Using blue-green light at night and blue-blockers during the day to improves adaptation to night work: a pilot study. Prog Neuropsychopharmacol Biol Psychiatry 34: 1236-1242.

Schlosser Covell GE, Dhawan PS, Lee Iannotti JK, Hoffman-Snyder CR, Wellik KE, Caselli RJ, Woodruff BK, Wingerchuk DM, Demaerschalk BM. 2012. Disrupted daytime activity and altered sleep-wake patterns may predict transition to mild cognitive impairment or dementia: a critically appraised topic. Neurologist 18: $426-429$.

Schweitzer PK, Randazzo AC, Stone K, Erman M, Walsh JK. 2006. Laboratory and field studies of naps and caffeine as practical countermeasures for sleep-wake problems associated with night work. Sleep 29: 39-50

Sei H, Sano A, Oishi K, Fujihara H, Kobayashi H, Ishida N, Morita Y. 2003. Increase of hippocampal acetylcholine release at the onset of dark phase is suppressed in a mutant mice model of evening-type individuals. Neuroscience 117: 785-789.

Sei H, Oishi K, Sano A, Seno H, Ohmori T, Morita Y, Ishida N. 2006. Clock mutant mice with Jcl/ICR background shows an impaired learning ability in water maze, but not in passive avoidance, at the beginning of dark phase. Congenit Anom (Kyoto) 46: 81-85.

Sellix MT. 2015. Circadian clock function in the mammalian ovary. J Biol Rhythms 30: 7-19.

Sellix MT, Evans JA, Leise TL, Castanon-Cervantes O, Hill DD, DeLisser P, Block GD, Menaker M, Davidson AJ. 2012. Aging differentially affects the re-entrainment response of central and peripheral circadian oscillators. J Neurosci 32: 16193-16202.

Sharkey KM, Eastman CI. 2002. Melatonin phase shifts human circadian rhythms in a placebo-controlled simulated night-work study. Am J Physiol Regul Integr Comp Physiol 282: R454-R463.

Sharkey KM, Fogg LF, Eastman CI. 2001. Effects of melatonin administration on daytime sleep after simulated night shift work. J Sleep Res 10: 181-192. 
Sharma SK, Sherff CM, Shobe J, Bagnall MW, Sutton MA, Carew TJ. 2003. Differential role of mitogen-activated protein kinase in three distinct phases of memory for sensitization in Aplysia. J Neurosci 23: 3899-3907.

Shaw PJ, Tononi G, Greenspan RJ, Robinson DF. 2002. Stress response genes protect against lethal effects of sleep deprivation in Drosophila. Nature 417: $287-291$.

Shimizu K, Okada M, Nagai K, Fukada Y. 2003. Suprachiasmatic nucleus circadian oscillatory protein, a novel binding partner of K-Ras in the membrane rafts, negatively regulates MAPK pathway. J Biol Chem 278: 14920-14925.

Shimizu K, Phan T, Mansuy IM, Storm DR. 2007. Proteolytic degradation of SCOP in the hippocampus contributes to activation of MAP kinase and memory. Cell 128: 1219-1229.

Shimizu K, Mackenzie SM, Storm DR. 2010. SCOP/PHLPP and its functional role in the brain. Mol Biosyst 6: 38-43.

Signal TL, Gander PH, van den Berg MJ, Graeber RC. 2013. In-flight sleep of flight crew during a 7-hour rest break: implications for research and flight safety. Sleep 36: 109-115.

Silva EJ, Wang W, Ronda JM, Wyatt JK, Duffy JF. 2010. Circadian and wake-dependent influences on subjective sleepiness, cognitive throughput, and reaction time performance in older and young adults. Sleep 33: 481-490.

Sloan MA, Levenson J, Tran Q, Kerbeshian M, Block GD, Eskin A. 1999. Aging affects the ocular circadian pacemaker of Aplysia californica. J Biol Rhythms 14: 151-159.

Smarr BL, Jennings KJ, Driscoll JR, Kriegsfeld LJ. 2014. A time to remember: the role of circadian clocks in learning and memory. Behav Neurosci 128: $283-303$.

Smith MR, Fogg LF, Eastman CI. 2009. Practical interventions to promote circadian adaptation to permanent night shift work: study 4. J Biol Rhythms 24: 161-172.

Srinivasan V, Singh J, Pandi-Perumal SR, Brown GM, Spence DW, Cardinali DP. 2010. Jet lag, circadian rhythm sleep disturbances, and depression: the role of melatonin and its analogs. Adv Ther 27: 796-813.

Stefanova NA, Maksimova KY, Kiseleva E, Rudnitskaya EA, Muraleva NA, Kolosova NG. 2015. Melatonin attenuates impairments of structural hippocampal neuroplasticity in OXYS rats during active progression of Alzheimer's disease-like pathology. J Pineal Res doi: 10.1111/jpi.12248.

Stephan FK. 2002. The "other" circadian system: food as a Zeitgeber. J Biol Rhythms 17: 284-292.

Stevens RG, Zhu Y. 2015. Electric light, particularly at night, disrupts human circadian rhythmicity: is that a problem? Philos Trans $R$ Soc Lond B Biol Sci 370: pii: 20140120 .

Takahashi Y, Sawa K, Okada T. 2013. The diurnal variation of performance of the novel location recognition task in male rats. Behav Brain Res 256: $488-493$.

Tanenhaus AK, Zhang J, Yin JCP. 2012. In vivo circadian oscillation of dCREB2 and NF-кB activity in the Drosophila nervous system. PLoS One 7: e45130.

Tapp WN, Holloway FA. 1981. Phase shifting circadian rhythms produces retrograde amnesia. Science 211: 1056-1058.

Tononi G, Cirelli C. 2014. Sleep and the price of plasticity: from synaptic and cellular homeostasis to memory consolidation and integration. Neuron 81: $12-34$.

Tranah GJ, Blackwell T, Stone KL, Ancoli-Israel S, Paudel ML, Ensrud KE, Cauley JA, Redline S, Hillier TA, Cummings SR, et al. 2011. Circadian activity rhythms and risk of incident dementia and mild cognitive impairment in older women. Ann Neurol 70: 722-732.

U.S. Bureau of Labor Statistics. 2005. Workers on flexible and shift schedules in 2004 summary. In Division of Labor Force Statistics. U.S. Government.

Valentinuzzi VS, Kolker DE, Vitaterna MH, Ferrari EAM, Takahashi JS, Turek FW. 2001. Effect of circadian phase on context and cued fear conditioning in C57BL/6J mice. Anim Learn Behav 29: 133-142.

Valentinuzzi VS, Menna-Barreto L, Xavier GF. 2004. Effect of circadian phase on performance of rats in the Morris water maze task. J Biol Rhythms 19: 312-324.

Valentinuzzi VS, Neto SP, Carneiro BT, Santana KS, Araújo JF, Ralph MR. 2008. Memory for time of training modulates performance on a place conditioning task in marmosets. Neurobiol Learn Mem 89: 604-607.

Van der Zee EA, Havekes R, Barf RP, Hut RA, Nijholt IM, Jacobs EH, Gerkema MP. 2008. Circadian time-place learning in mice depends on Cry genes. Curr Biol 18: 844-848.

Videnovic A, Lazar AS, Barker RA, Overeem S. 2014. 'The clocks that time us'-circadian rhythms in neurodegenerative disorders. Nat Rev Neurol 10: $683-693$.

Wagatsuma A, Sugai R, Chono K, Azami S, Hatakeyama D, Sadamoto H, Itoi E. 2004. The early snail acquires the learning. Comparison of scores for conditioned taste aversion between morning and afternoon. Acta Biol Hung 55: 149-155.

Walsh JK, Schweitzer PK, Sugerman JL, Muehlbach MJ. 1990. Transient insomnia associated with a 3-hour phase advance of sleep time and treatment with zolpidem. J Clin Psychopharmacol 10: 184-189.

Walsh JK, Randazzo AC, Stone KL, Schweitzer PK. 2004. Modafinil improves alertness, vigilance, and executive function during simulated night shifts. Sleep 27: 434-439.

Walsh CM, Blackwell T, Tranah GJ, Stone KL, Ancoli-Israel S, Redline S, Paudel M, Kramer JH, Yaffe K. 2014. Weaker circadian activity rhythms are associated with poorer executive function in older women. Sleep 37: 2009-2016.

Wang LM, Suthana NA, Chaudhury D, Weaver DR, Colwell CS. 2005. Melatonin inhibits hippocampal long-term potentiation. Eur J Neurosci 22: $2231-2237$.

Wang LM, Dragich JM, Kudo T, Odom IH, Welsh DK, O'Dell TJ, Colwell CS. 2009. Expression of the circadian clock gene Period2 in the hippocampus: possible implications for synaptic plasticity and learned behaviour. ASN Neuro 1: pii: e00012.

Wardlaw SM, Phan TX, Saraf A, Chen X, Storm DR. 2014. Genetic disruption of the core circadian clock impairs hippocampus-dependent memory. Learn Mem 21: 417-423.

Weber P, Kula-Eversole E, Pyza E. 2009. Circadian control of dendrite morphology in the visual system of Drosophila melanogaster. PLoS One 4: e4290.

Wertz AT, Ronda JM, Czeisler CA, Wright KP Jr. 2006. Effects of sleep inertia on cognition. JAMA 295: 163-164.

Whitmore D, Cermakian N, Crosio C, Foulkes NS, Pando MP, Travnickova Z, Sassone-Corsi P. 2000. A clockwork organ. Biol Chem 381: $793-800$.

Wittmann M, Dinich J, Merrow M, Roenneberg T. 2006. Social jetlag: misalignment of biological and social time. Chronobiol Int 23: 497-509.

Woodruff ER, Greenwood BN, Chun LE, Fardi S, Hinds LR, Spencer RL. 2015. Adrenal-dependent diurnal modulation of conditioned fear extinction learning. Behav Brain Res 286: 249-255.

Wright KP, Hull JT, Czeisler CA. 2002. Relationship between alertness, performance, and body temperature in humans. Am J Physiol Regul Integr Comp Physiol 283: R1370-R1377.

Wright KP Jr, Hull JT, Hughes RJ, Ronda JM, Czeisler CA. 2006. Sleep and wakefulness out of phase with internal biological time impairs learning in humans. J Cogn Neurosci 18: 508-521.

Wright KP, Lowry CA, Lebourgeois MK. 2012. Circadian and wakefulness-sleep modulation of cognition in humans. Front $\mathrm{Mol}$ Neurosci 5: 50.

Wright KP, Bogan RK, Wyatt JK. 2013. Shift work and the assessment and management of shift work disorder (SWD). Sleep Med Rev 17: 41-54.

Wulff K, Gatti S, Wettstein JG, Foster RG. 2010. Sleep and circadian rhythm disruption in psychiatric and neurodegenerative disease. Nat Rev Neurosci 11: 589-599.

Wyatt JK, Cajochen C, Ritz-De Cecco A, Czeisler CA, Dijk DJ. 2004. Low-dose repeated caffeine administration for circadian-phase-dependent performance degradation during extended wakefulness. Sleep 27: 374-381.

Yamazaki S, Numano R, Abe M, Hida A, Takahashi R, Ueda M, Block GD, Sakaki Y, Menaker M, Tei H. 2000. Resetting central and peripheral circadian oscillators in transgenic rats. Science 288: 682-685.

Yamazaki S, Straume M, Tei H, Sakaki Y, Menaker M, Block GD. 2002. Effects of aging on central and peripheral mammalian clocks. Proc Natl Acad Sci 99: 10801-10806.

Yoo SH, Yamazaki S, Lowrey PL, Shimomura K, Ko CH, Buhr ED, Siepka SM, Hong HK, Oh WJ, Yoo OJ, et al. 2004. PERIOD2::LUCIFERASE real-time reporting of circadian dynamics reveals persistent circadian oscillations in mouse peripheral tissues. Proc Natl Acad Sci 101: 5339-5346.

Zee PC, Goldstein CA. 2010. Treatment of shift work disorder and jet lag. Curr Treat Options Neurol 12: 396-411.

Zelinski EL, Deibel SH, McDonald RJ. 2014. The trouble with circadian clock dysfunction: multiple deleterious effects on the brain and body. Neurosci Biobehav Rev 40: 80-101.

Zhdanova IV, Masuda K, Quasarano-Kourkoulis C, Rosene DL, Killiany RJ, Wang S. 2011. Aging of intrinsic circadian rhythms and sleep in a diurnal nonhuman primate, Macaca mulatta. J Biol Rhythms 26: 149-159.

Zimmer C, Boos M, Bertrand F, Robin JP, Petit O. 2011. Behavioural adjustment in response to increased predation risk: a study in three duck species. PLoS One 6: e18977.

Received April 22, 2015; accepted in revised form June 29, 2015. 


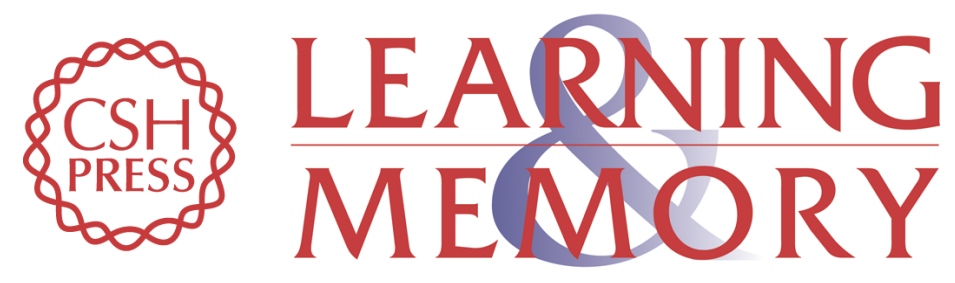

\title{
Synchrony and desynchrony in circadian clocks: impacts on learning and memory
}

\author{
Harini C. Krishnan and Lisa C. Lyons
}

Learn. Mem. 2015, 22:

Access the most recent version at doi:10.1101/Im.038877.115

\begin{aligned} & \hline References $\begin{array}{l}\text { This article cites } 255 \text { articles, } 48 \text { of which can be accessed free at: } \\ \text { http://learnmem.cshlp.org/content/22/9/426.full.html\#ref-list-1 }\end{array} \\ & \begin{aligned} \text { Creative } \\ \text { Commons } \\ \text { License }\end{aligned} \begin{array}{l}\text { This article is distributed exclusively by Cold Spring Harbor Laboratory Press for the } \\ \text { first } 12 \text { months after the full-issue publication date (see } \\ \text { http://learnmem.cshlp.org/site/misc/terms.xhtml). After } 12 \text { months, it is available under } \\ \text { a Creative Commons License (Attribution-NonCommercial } 4.0 \text { International), as } \\ \text { described at http://creativecommons.org/licenses/by-nc/4.0/. }\end{array} \\ & \begin{array}{c}\text { Receive free email alerts when new articles cite this article - sign up in the box at the } \\ \text { top right corner of the article or click here. }\end{array} \\ &$\hline\end{aligned}

